Revue bibliographique pour le domaine irano-aryen

\title{
Emad Matin. "The Achaemenid Settlement of Dashtestan (Borazjan): A View from Persepolis"
}

\section{Luca Colliva}

\section{Q OpenEdition \\ 1 Journals}

\section{Electronic version}

URL: https://journals.openedition.org/abstractairanica/51766

DOI: 10.4000/abstractairanica.51766

ISSN: 1961-960X

Publisher:

CNRS (UMR 7528 Mondes iraniens et indiens), Éditions de l'IFRI

\section{Electronic reference}

Luca Colliva, "Emad Matin. "The Achaemenid Settlement of Dashtestan (Borazjan): A View from Persepolis"'", Abstracta Iranica [Online], Volume 42-43 | 2021, document 9, Online since 30 December 2020, connection on 13 December 2022. URL: http://journals.openedition.org/abstractairanica/51766 ; DOI: https://doi.org/10.4000/abstractairanica.51766

This text was automatically generated on 13 December 2022.

All rights reserved 


\title{
Emad Matin. "The Achaemenid Settlement of Dashtestan (Borazjan): A View from Persepolis"
}

\author{
Luca Colliva
}

\section{REFERENCES}

Emad Matin. "The Achaemenid Settlement of Dashtestan (Borazjan): A View from

Persepolis", East \& West n.s. 1/2, 2020, p. 179-210

1 The article, published in the first number of the new series of East \& West journal edited by ISMEO, analyses all the archaeological and historical data available to date for the Dashtestan county from the Achaemenid period, in order to demonstrate the presence of the settlement of Tamukkan (Taoce, TaH(u)makka) in this area and propose for it an urban model similar to that recently hypothesized for the Achaemenid settlements of Persepolis and Pasargadae.

2 The author examines the data of the excavations of Charkhab, Sang-e Siah and Bardake Siah, the archaeological surveys in the Dashtestan county in the Bushehr province, and the studies of historical sources relating to this area and the settlement of Tamukkan. The analysis of the data and the comparison with the recent studies of the sites of Pasargadae and Persepolis allow the author to strongly re-propose the presence of Tamukkan in this area. Moreover, these comparisons lead the author to suggest, also for Tamukkan, a "diffuse" urban model which seems to characterise the major centres founded in Fars in the Achaemenid period. 


\section{AUTHORS}

\section{LUCA COLLIVA}

Alma Mater Studiorum - Università di Bologna 